\title{
Ultrasonic-assisted extraction and functional properties of wampee seed protein
}

\author{
Yong LIU ${ }^{1 \star}$, Xiu-Yun MA ${ }^{1}$, Lin-Na LIU ${ }^{1}$, Yu-Ping XIE ${ }^{1}$, Yong-Jian $\mathrm{KE}^{1}$, Zhu-Jiao CAI ${ }^{1}$, Guo-Jie WU ${ }^{2}$
}

\begin{abstract}
The wampee seed protein (WSP) was extracted by the ultrasonic and alkaline solution. Response surface methodology was used to optimize the extraction parameters for obtaining the highest protein yield, and the protein's functional properties such as protein solubility, water and oil holding capacity, and emulsifying and foaming properties ware studied in comparison with soy protein isolate (SPI). The results showed that ultrasonic time and $\mathrm{pH}$ significantly influenced the yield, and the optimal extraction conditions were achieved when solid-solvent ratio, ultrasonic time and $\mathrm{pH}$ were $1: 29 \mathrm{~g} / \mathrm{mL}, 64 \mathrm{~min}$ and 12, respectively, under which the yield was $15.06 \%$. The functional property tests revealed that the WSP's solubility was higher than that of SPI and its isoelectric point was near 3.0. Compared with SPI, the oil holding capacity, emulsion activity index and emulsion stability index of WSP were significantly higher, but its water holding capacity, foaming capacity and foaming stability were significantly lower.
\end{abstract}

Keywords: ultrasonic extraction; protein; response surface methodology; functional property.

Practical Application: The optimal extraction conditions for wampee seed protein are desirable and practical, and the wampee seed protein can be used as a new protein source for its functional properties.

\section{Introduction}

Wampee (Clausena lansium Skeels) is a tropical species of the Rutaceae family and is widely distributed in southern China, southeastern Asia, North America and warm areas of the world (Shen et al., 2012; Xu et al., 2014). The fruit of wampee is about $2 \mathrm{~cm}$ in diameter with 1-3 seeds and is nutritious and attractive in color (Prasad et al., 2010). In traditional Chinese medicine, the leaves, fruits, and seeds of wampee are used to treat cough, asthma, dermatological, viral hepatitis, ulcers, digestive disorder and gastro-intestinal diseases (Du et al., 2015; Shen et al., 2012). The fruits of wampee are often eaten fresh or made into pie, jam, wine, jelly and juice (Prasad et al., 2010; $\mathrm{Xu}$ et al., 2014). The seeds, about $30 \%$ of the fruit weight, are the abundant by-products of the fruit processing and have not been fully investigated.

Recently, recovery of bioactive compounds from food processing by-products is of great interest (Castro-Muñoz et al., 2016; Roselló-Soto et al., 2015). Proteins are important substances for human beings because they provide the macronutrients necessary and confer the physicochemical and functional properties to foods (Chirinos et al., 2017). Natural plant-derived proteins are currently gaining much interest as a sustainable alternative to animal-based proteins for the food security and the rising cost of animal-derived proteins (Du et al., 2018; Preece et al., 2017). Therefore, protein extraction from cereals, legumes, algae, seeds and their by-products has been widely studied (Piotrowicz \& Salas-Mellado, 2017). The wampee seeds are rich in protein and are the ideal raw materials for exploiting as a new protein resource because the proteins from seeds have a significant biologically activity (Du et al., 2018). However, to the best of our knowledge, there are no reports about the study on extraction and functional properties of wampee seed protein. Therefore, it is important to recover the wampee seed protein to develop high value-added products.

Extraction is the key step for the isolation and recovery of proteins. Many methods like traditional alkaline, salt, reverse micelle, organic solvent, and enzyme extraction have been used to extract plant proteins (Ge et al., 2016). However, there are several latent disadvantages in these methods. Therefore, comprehensive extraction method is needed to develop the extraction of proteins. Ultrasonic-assisted extraction (UAE) is an efficient extraction technique due to its remarkable advantages of short extraction time, high extraction yield and low solvent amount (Zou et al., 2017). Alkaline extraction (AE) is the most common method for protein extraction due to its simplicity and low cost (Phongthai et al., 2016). Response surface methodology (RSM) is an effective statistical tool to optimize the extraction parameters and investigate the significance of the effect of parameters on the response variable (He et al., 2016). In this work, $\mathrm{UAE}$ and $\mathrm{AE}$ were combined to extract wampee seed protein for their advantages, and RSM was used to optimize the extraction parameters (solid to solvent ratio, ultrasonic time and $\mathrm{pH}$ ) to achieve the highest protein extraction yield and investigate the effect of parameters on the yield. Moreover, the functional properties of wampee seed protein were studied. 


\section{Experimental}

\subsection{Materials and chemicals}

Wampee seeds were provided by a farmer named Jinhua $\mathrm{Li}$ from Zhaoqing city, Guangdong province, China. Bovine serum albumin (BSA), Coomassie brilliant blue G-250 and sodium lauryl sulfonate (SDS) were from Macklin Biochemical Technology Co. Ltd. (Shanghai, China). Peanut oil and soy protein isolate (SPI) were purchased from Yingma Food Co. Ltd. (Guangzhou, China) and Yixin Biological Technology Co., Ltd. (Guangzhou, China), respectively.

\subsection{Extraction of wampee seed protein and determination of extraction yield}

Fresh wampee seeds were washed with tap water, dried in a blast oven at $80{ }^{\circ} \mathrm{C}$ for $48 \mathrm{~h}$. The dried seeds were milled by a pulverizer and passed through a 100 -mesh sieve to obtain seed powder. For each extraction, $0.1000 \mathrm{~g}$ of the powder and solvent with different $\mathrm{pH}$ were mixed in a 10 - $\mathrm{mL}$ glass bottle, and the bottle was sealed and placed in an ultrasonic cleaner (240 W, $40 \mathrm{kHz}, \mathrm{JP}-020 \mathrm{~S}$, Jiemeng, China) to extract the seed protein. After extraction, the bottle was centrifuged at $4{ }^{\circ} \mathrm{C}$ in a refrigerated centrifuge (TGL-16M, Xiangli, China) at $7508 \times \mathrm{g}$ for $20 \mathrm{~min}$ and the protein content in the supernatant was determined according to the Bradford method (Bradford, 1976). Briefly, the supernatant was collected and diluted by a $10 \mathrm{~mL}$ volumetric bottle for each extraction, $1.0 \mathrm{~mL}$ of the diluted solution and $5.0 \mathrm{~mL}$ of Coomassie brilliant blue G-250 solution were mixed at room temperature for $2 \mathrm{~min}$. Then the mixture absorbance was determined at $595 \mathrm{~nm}$ by a UV-vis spectrophotometer (T6, Puxi, China). The protein concentration in the $10 \mathrm{~mL}$ volumetric bottle was calculated based on the standard curve of BSA solutions $(0-100 \mu \mathrm{g} / \mathrm{mL})$, and the protein weight was equal to the protein concentration multiplied by the volumetric bottle volume $(10 \mathrm{~mL})$. The protein extraction yield was calculated as follows (Equation 1):
Extraction yield $(\%)=\frac{\text { Protein weight }(\mathrm{g})}{\text { Powder weight }(\mathrm{g})} \times 100$

\subsection{Optimization design}

Based on the principle of Box-Behnken (BBD) design, solid to solvent ratio $(A)$, ultrasonic time $(B)$ and $\mathrm{pH}(C)$ as the extraction parameters for the protein extraction yield $(Y)$ calculated by Equation 1 were optimized by RSM. The independent variable levels and the design test results were presented in Table 1.

\subsection{Preparation of seed protein samples}

The extraction supernatant obtained under optimized extraction conditions was adjusted to $\mathrm{pH} 3.0$ (isoelectric point of seed protein) and stand for $6 \mathrm{~h}$ at $4{ }^{\circ} \mathrm{C}$. The precipitate was washed twice using deionized water and centrifuged twice under above centrifugation condition. Then the washed precipitate was redispersed in deionized water and the $\mathrm{pH}$ value of the solution was adjusted to 7.0. Finally, the solution was freeze-dried for $48 \mathrm{~h}$ by a freeze dryer (Lab-1A-50E, Boyikang, China) to obtain the wampee seed protein.

\subsection{Functional properties of wampee seed protein}

\subsubsection{Solubility}

The protein solubility was determined according to Zou (Zou et al., 2017) with a slight modification. $10.0 \mathrm{mg}$ of sample was dispersed in $8 \mathrm{~mL}$ of deionized water and the $\mathrm{pH}$ was adjusted to $2,2.5,3,3.5,4,4.5,5,6,7,8,9$ and 10 with either $1 \mathrm{~mol} / \mathrm{L} \mathrm{HCl}$ or $1 \mathrm{~mol} / \mathrm{L} \mathrm{NaOH}$. The mixture was stirred at room temperature for $30 \mathrm{~min}$. The volume of solutions was adjusted to $10 \mathrm{~mL}$ by the corresponding $\mathrm{pH}$ solutions. The solutions were centrifuged at $7508 \times \mathrm{g}$ for $20 \mathrm{~min}$. Protein content in the supernatant was determined by the above Bradford method. Protein solubility was calculated as follows (Equation 2):

Table 1. Box-Behnken design for independent variables and their extraction yield.

\begin{tabular}{clccc}
\hline \multirow{2}{*}{ Run } & \multicolumn{3}{c}{ Uncoded values (coded values) of independent variables } & \multicolumn{1}{c}{$Y(\%)$} \\
\cline { 2 - 4 } & $A(\mathrm{~g} / \mathrm{mL})$ & $B(\mathrm{~min})$ & $12(0)$ & $12.26 \pm 0.18$ \\
2 & $1: 20(-1)$ & $50(-1)$ & $13(1)$ & $12.91 \pm 0.16$ \\
2 & $1: 40(1)$ & $60(0)$ & $12(0)$ & $13.45 \pm 0.15$ \\
3 & $1: 40(1)$ & $50(-1)$ & $12(0)$ & $14.92 \pm 0.14$ \\
4 & $1: 30(0)$ & $60(0)$ & $11(-1)$ & $13.62 \pm 0.17$ \\
5 & $1: 30(0)$ & $70(1)$ & $12(0)$ & $15.02 \pm 0.11$ \\
6 & $1: 30(0)$ & $60(0)$ & $11(-1)$ & $13.83 \pm 0.17$ \\
7 & $1: 40(1)$ & $60(0)$ & $12(0)$ & $13.56 \pm 0.16$ \\
8 & $1: 20(-1)$ & $70(1)$ & $12(0)$ & $13.11 \pm 0.15$ \\
9 & $1: 40(1)$ & $70(1)$ & $12(0)$ & $15.06 \pm 0.13$ \\
10 & $1: 30(0)$ & $60(0)$ & $11(-1)$ & $13.11 \pm 0.19$ \\
11 & $1: 30(0)$ & $50(-1)$ & $11(-1)$ & $11.87 \pm 0.16$ \\
12 & $1: 20(-1)$ & $60(0)$ & $13(1)$ & $14.64 \pm 0.17$ \\
13 & $1: 30(0)$ & $70(1)$ & $13(1)$ & $13.12 \pm 0.16$ \\
14 & $1: 30(0)$ & $50(-1)$ & $13(1)$ & $14.28 \pm 0.18$ \\
15 & $1: 20(-1)$ & $60(0)$ & \\
\hline
\end{tabular}

Notes: solid to solvent ratio $(A)$, ultrasonic time $(B), \mathrm{pH}(C)$ and extraction yield $(Y)$. 
Solubility $(\%)=\frac{\text { Protein content in supernatant }}{\text { Total protein content in sample }} \times 100$

\subsubsection{Water and oil holding capacity}

The water and oil holding the capacity of samples were determined according to Yllmaz (Yllmaz \& Hüriyet, 2017) and Saha (Saha \& Deka, 2017) with some modification. $0.3 \mathrm{~g}$ of sample and $5.0 \mathrm{~mL}$ deionized water or peanut oil were mixed in a $10 \mathrm{~mL}$ centrifuge tube, and the mixture vigorously vortexed. After mixing, the mixture stood for $30 \mathrm{~min}$ at room temperature and then centrifuged at $3003 \times \mathrm{g}$ for $15 \mathrm{~min}$. The water holding capacity (WHC) and oil holding capacity $(\mathrm{OHC})$ were calculated by the following Equation 3:

WHC or OHC $(g / g)=\frac{W_{2}-W_{1}}{W_{0}}$

where $\mathrm{W}_{0}$ is the weight of the dry sample $(\mathrm{g}), \mathrm{W}_{1}$ is the weight of the dry sample and tube $(\mathrm{g})$, and $\mathrm{W}_{2}$ is the weight of the sediment and tube $(\mathrm{g})$.

\subsubsection{Emulsifying properties}

The emulsion activity index (EAI) and emulsion stability index (ESI) of the samples were measured according to Jiang (Jiang et al., 2009) with a slight modification. Emulsions were prepared by adding $5.0 \mathrm{~mL}$ of peanut oil to $15.0 \mathrm{~mL}$ of $1.0 \mathrm{mg} / \mathrm{mL}$ protein solution followed by homogenization at $24000 \mathrm{rpm}$ for 1 min using a high-speed homogenizer (XHF-D, Xinzhi, China). $50 \mu \mathrm{L}$ of emulsion taken from the bottom of the beaker was mixed with $5.0 \mathrm{~mL}$ of $0.1 \%$ SDS solution immediately at 0 and $10 \mathrm{~min}$. The mixture vigorously vortexed by a vortex mixer and the absorbance of the mixture was determined at $500 \mathrm{~nm}$ using a UV-vis spectrophotometer. EAI and ESI were calculated using the Equation 4 and 5:

$$
\begin{aligned}
& \operatorname{EAI}\left(\mathrm{m}^{2} / \mathrm{g}\right)=\frac{4.606 \times \mathrm{A}_{0} \times \mathrm{D}}{\mathrm{C} \times(1-\varphi) \times 10000} \\
& \operatorname{ESI}(\%)=\frac{\mathrm{A}_{10}}{\mathrm{~A}_{0}} \times 100
\end{aligned}
$$

where $A_{0}$ and $A_{10}$ are the absorbances of the mixture at 0 min and 10 min, respectively; $\mathrm{D}$ is the dilution factor (100); $\mathrm{C}$ is the protein concentration $(\mathrm{g} / \mathrm{mL})$ before emulsification; $\varphi$ is the oil volume fraction of the emulsion (0.25).

\subsubsection{Foaming properties}

The foaming capacity (FC) and foaming stability (FS) of the samples were measured as reported by Phongthai (Phongthai et al., 2016) with a slight modification. $50.0 \mathrm{~mL}$ of $0.1 \%(\mathrm{w} / \mathrm{v})$ protein solution in a $150 \mathrm{~mL}$ high-type beaker was homogenized at $24000 \mathrm{rpm}$ for $1 \mathrm{~min}$ by a high-speed homogenizer. The total volume was measured at 0 and $10 \mathrm{~min}$. FC and FS were calculated using the Equation 6 and 7:

$\mathrm{FC}(\%)=\frac{\mathrm{V}_{1}-\mathrm{V}_{0}}{\mathrm{~V}_{0}} \times 100$
$\mathrm{FS}(\%)=\frac{\mathrm{V}_{2}-\mathrm{V}_{0}}{\mathrm{~V}_{1}-\mathrm{V}_{0}} \times 100$

where $\mathrm{V}_{0}$ is the volume of the protein solution before homogenization; $\mathrm{V}_{1}$ is the volume of the protein solution after homogenization $(0 \mathrm{~min}) ; \mathrm{V}_{2}$ is the volume of the protein solution after homogenization (10 $\mathrm{min})$.

\subsection{Statistical analyses}

The experimental data were taken as the average of three test results. One-way ANOVA and Duncan's test were performed by IBM SPSS software (version 20.0). Analysis of variance and extraction optimization was performed using Design Expert software (version 8.0 ). $\mathrm{P}<0.05$ was statistically significant.

\section{Results and Discussion}

\subsection{Optimization of extraction parameters by RSM}

\subsubsection{Model fitting and effect analyses}

According to the experimental design and results in Table 1, the model for the extraction of wampee seed protein (WSP) was fitted by Design-Expert software. The model for the extraction yield $(Y, \%)$ was achieved by using the quadratic polynomial regression equation of solid-solvent ratio $(A, \mathrm{~g} / \mathrm{mL})$, ultrasonic time $(B, \min )$ and $\mathrm{pH}(C)$. The optimized model expressed in the form of coded values was as follows (Equation 8):

$Y=15.00+0.17 A+0.37 B+0.32 C-0.41 A B-0.83 A C+$

$0.25 B C-1.15 A^{2}-0.75 B^{2}-0.63 C^{2}$

Analysis of variance (ANOVA) in Table 2 showed that the determination coefficient $\left(R^{2}\right)$ and the adjusted determination coefficient ( $R 2$ adj) were 0.9864 and 0.9619 , respectively. These results showed the model was properly interpreted for the test data (Deng et al., 2016) and the data were good in agreement with the predicted values (Yan et al., 2016). The model for the yield was highly significant for the $p$-value $(0.0004)$ that was less than 0.05 . The lack of fit was not significant for the $p$-value $=0.0841$, which exhibited the test data could be correctly explained. The coefficient of variation (1.40\%) was very low, showing the test results were reliable.

The $p$-value is a tool to assess the significance of the linear, quadratic, and interaction term coefficients. Table 2 shows that the linear terms $\left(B\right.$ and $C$ ) and the quadratic terms $\left(A^{2}, B^{2}\right.$, and $\left.C^{2}\right)$ significantly affected on the yield $(Y)$ because their $p$-values were less than 0.05 , but that of the linear term $(A)$ was not significant for its $p$-value $>0.05$. According to the $p$-values in Table 2 , the important effects of the three variables on the yield were in the order of ultrasonic time $(B), \mathrm{pH}(C)$ and solid-solvent ratio $(A)$. The interaction terms of $A B, A C$, and $B C$ also significantly influenced on the yield for their $p$-value $>0.05$. These statistical results showed that the effects of the variables of $B$ and $C$ and the interactions of $A B, A C$, and $B C$ on the yield $(Y)$ were significant. 
Table 2. Analysis of variance for response surface quadratic model.

\begin{tabular}{|c|c|c|c|c|c|}
\hline Source & Sum of squares & Degree of freedom & Mean square & $F$-value & $p$-value (Prob. $>F$ ) \\
\hline Model & 13.27 & 9 & 1.47 & 40.32 & $0.0004^{* *}$ \\
\hline$A$ & 0.22 & 1 & 0.22 & 6.05 & 0.0573 \\
\hline$B$ & 1.12 & 1 & 1.12 & 30.57 & $0.0027^{\star \star}$ \\
\hline C & 0.79 & 1 & 0.79 & 21.72 & $0.0055^{\star *}$ \\
\hline$A B$ & 0.67 & 1 & 0.67 & 18.39 & $0.0078^{\star *}$ \\
\hline$A C$ & 2.77 & 1 & 2.77 & 75.84 & $0.0003^{* *}$ \\
\hline$B C$ & 0.26 & 1 & 0.26 & 6.98 & $0.0459^{*}$ \\
\hline$A^{2}$ & 4.90 & 1 & 4.90 & 134.16 & $<0.0001^{\star *}$ \\
\hline$B^{2}$ & 2.09 & 1 & 2.09 & 57.20 & $0.0006^{* *}$ \\
\hline$C^{2}$ & 1.44 & 1 & 1.44 & 39.46 & $0.0015^{\star \star}$ \\
\hline Residual & 0.18 & 5 & 0.037 & & \\
\hline Lack of fit & 0.17 & 3 & 0.057 & 11.05 & 0.0841 \\
\hline Pure error & 0.01 & 2 & 0.0052 & & \\
\hline Cor. total & 13.45 & 14 & & & \\
\hline$R^{2}=0.9864$ & $R 2 \mathrm{adj}=0.9619$ & C.V. $=1.40 \%$ & & & \\
\hline
\end{tabular}

Notes: ${ }^{\star}$ Significant at $p<0.05 ;{ }^{*}$ Highly significant at $p<0.01$. A: Solid to solvent ratio, B: Ultrasonic time, $\mathrm{C}$ : $\mathrm{pH}, \mathrm{AB}$ : Interaction of solid to solvent ratio and ultrasonic time, $\mathrm{AC}$ : Interaction of solid to solvent ratio and $\mathrm{pH}, \mathrm{BC}$ : Interaction of solid to solvent ratio and $\mathrm{pH}, \mathrm{A}^{2}$ : Quadratic square of solid to solvent ratio, $\mathrm{B}^{2}$ : Quadratic square of ultrasonic time,

$\mathrm{C}^{2}$ : Quadratic square of $\mathrm{pH}$.

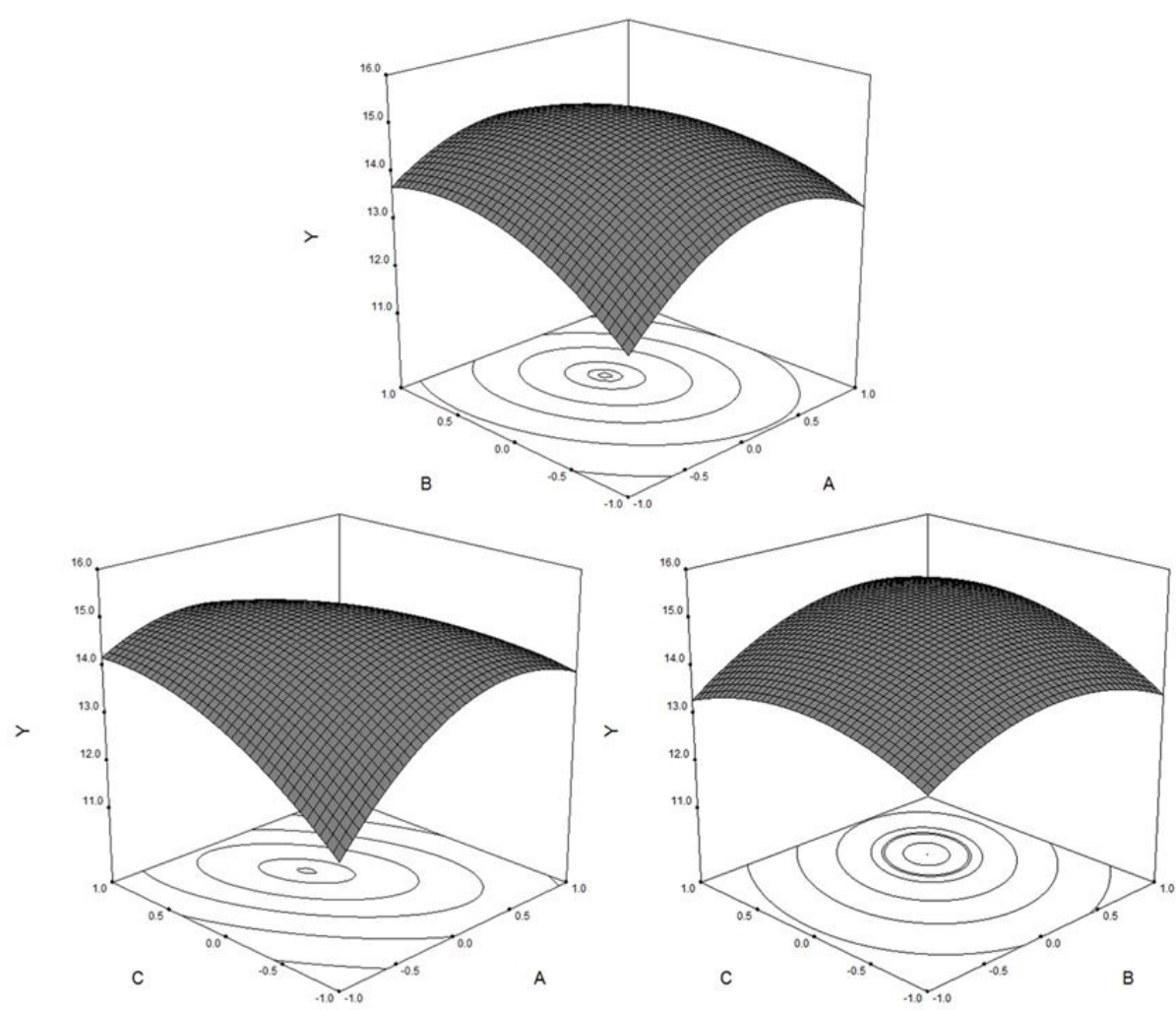

Figure 1. Response surface and contour plots of solid-solvent ratio $(A)$, ultrasonic time $(B), \mathrm{pH}(C)$ and protein extraction yield $(Y)$.

\subsubsection{Response surface analyses}

3 D response surface plots are provided a graphical explanation for the relationship between independent and dependent variables (Xie et al., 2015). The 3D response surfaces and 2D contours of solid-solvent ratio $(A)$, ultrasonic time $(B)$ and $\mathrm{pH}(C)$ on the yield $(Y)$ were plotted in Figure 1. As seen from
Figure 1, all 3D surfaces were convex and the highest point falls within the selected area, which indicated that the factor levels selected were reasonable. It can be seen from the observation of contours in Figure 1 that the interactions of $A B, A C$, and $B C$ significantly affected the yield $(Y)$, which was in agreement with the ANOVA in Table 2. 
As shown in Figure 1, the extraction yield $(Y)$ increased first and then reduced with the increase of solid-solvent ratio $(A)$. This may be ascribed to the ultrasonic energy distribution and the mass transfer principle. The higher the solid-solvent ratio, the higher the difference in protein mass concentration inside and outside the extraction matrix, which led to the increase of mass transport driving force in the extraction solution (Prasad et al., 2012; Şahin \& Şaml, 2013). This was good for protein extraction. However, the higher the solid-solvent ratio, the less the ultrasonic energy density per unit volume in the extraction solution (Xu et al., 2016), which was not good for protein extraction. Therefore, the solid-solvent ratio had the highest value in the curved surfaces.

The extraction yield $(Y)$ increased first and then decreased as ultrasonic time $(B)$ increased (Figure 1). Ultrasonic has the cavitation, mechanical agitation and thermal effects (Carrera et al., 2012; Tomšik et al., 2016) and can improve the protein to transport and release from the extracted matrix and consequently increase the protein yield. But the longer ultrasonic time can also result in the protein degradation and the lower protein yield (Carrera et al., 2012; Odabas \& Koca, 2016). Therefore, the ultrasonic time had the maximum value in the curved surfaces.

It was found that the extraction yield $(Y)$ increased first and then decreased as $\mathrm{pH}(C)$ increased (Figure 1). Alkaline treatment can break some bonds such as hydrogen bonds in the extraction matrix, so that the higher the $\mathrm{pH}$ value, the higher the protein extraction efficiency (Li et al., 2016). But the higher the $\mathrm{pH}$ value, the more the protein degradation, resulting in the low extraction yield and the loss of protein nutritional value (Xia et al., 2012). Therefore, the $\mathrm{pH}$ had the best value in the curved surfaces.

\subsubsection{Predictive model verification}

The optimum parameters for extracting wampee seed protein calculated by the Design-Expert software were: solid-solvent ratio of 1:28.57 g/mL, ultrasonic time of $63.57 \mathrm{~min}$ and $\mathrm{pH}$ of 12.42. Considering the practical operation, the optimum extraction parameters were adjusted to solid-solvent ratio of $1: 29 \mathrm{~g} / \mathrm{mL}$, ultrasonic time of $64 \mathrm{~min}$ and $\mathrm{pH}$ of 12 , under which the extraction yield $(15.06 \%)$ was close to the predicted value (15.12\%). The results showed that the model for the extraction of wampee seed protein was reliable and effective.

\subsection{Functional properties of wampee seed protein}

\subsubsection{Protein solubility}

The protein solubility is an important functional property because of its effect on other properties such as emulsification and foaming. The protein solubility of WSP and SPI obtained by Equation 2 was presented in Figure 2. It was observed in Figure 2 that the minimum solubility of WSP and SPI was at $\mathrm{pH} 3.0$ and 4.5 , respectively. This observation indicated that the isoelectric point (pI) of WSP and SPI was near $\mathrm{pH} 3.0$ and 4.5, respectively, which were similar to the reports of Kiwi fruit seed protein (pH 3.0) (Deng et al., 2014), commercial SPI ( $\mathrm{pH} 4.5$ ) (Horax et al., 2011), chickpea protein isolate (pH 4.5) (Kaur and

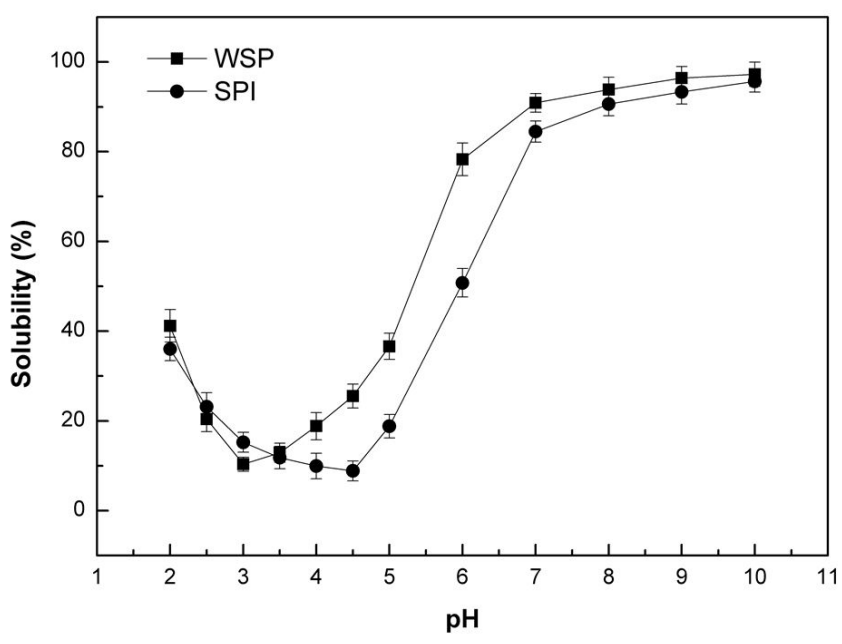

Figure 2. Protein solubility as a function of $\mathrm{pH}$. WSP: Wampee seed protein, SPI: Soy protein isolate.

Singh, 2007), black bean protein isolate ( $\mathrm{pH} 4.5)$ (Kudre et al., 2013) and peanut protein isolate ( $\mathrm{pH}$ 4.5) (Wu et al., 2009). The protein solubility of WSP and SPI increased when the $\mathrm{pH}$ was below or above the isoelectric point. At the isoelectric point, the protein had no net charges for the equal negative and positive charges, which resulted in the reduction of electrostatic repulsion that promoted the protein precipitation and the lowest solubility. When the $\mathrm{pH}$ value was far from the isoelectric point, the protein had more negative and positive charges, which led to the increase of electrostatic repulsion and hydration that promoted the protein dissolution and the higher solubility. The similar reports were found in Kiwi fruit seed protein (Deng et al., 2014), Fenugreek seed protein (Feyzi et al., 2015), duck liver protein (Zou et al., 2017) and rice bran protein (Phongthai et al., 2016). Moreover, the solubility of WSP was higher than that of SPI. The reason was that the protein molecules partially unfolded and the particle size of protein reduced by the ultrasonic treatment (Jain \& Anal, 2016; Zou et al., 2017).

\subsubsection{Water and oil holding capacity}

The water holding capacity (WHC) and oil holding capacity $(\mathrm{OHC})$ of samples calculated by Equation 3 were presented in Table 3. The WHC reflected the interaction between water and protein, which was related to conformational characteristics, amino acid composition, and hydrophilic and hydrophobic balance of protein (Du et al., 2018; Saha \& Deka, 2017). As seen from Table 3, The WHC of WSP (3.93) was significantly lower than that of SPI (5.38) for $p<0.05$, but higher than that of Kappaphycus alvarezii seaweed protein (2.22) (Suresh Kumar et al., 2014), Capia pepper seed protein (1.76) (Yllmaz \& Hüriyet, 2017), and rice bran protein (2.59) (Phongthai et al., 2016). The OHC of WSP (3.25) was significantly higher than that of SPI (2.19) for $p<0.05$. The lower WHC and higher OHC of WSP in comparison with SPI may be due to the less hydrophilic groups on WSP molecules to bind with water, but the more hydrophobic 
Table 3. Water holding, oil holding, emulsifying and foaming properties of WSP and SPI.

\begin{tabular}{crr}
\hline Property & WSP & SPI \\
\hline WHC (g/g) & $3.93 \pm 0.17^{\mathrm{b}}$ & $5.38 \pm 0.21^{\mathrm{a}}$ \\
OHC (g/g) & $3.25 \pm 0.13^{\mathrm{a}}$ & $2.19 \pm 0.16^{\mathrm{b}}$ \\
EAI (m/g) & $77.57 \pm 3.43^{\mathrm{a}}$ & $56.72 \pm 4.26^{\mathrm{b}}$ \\
ESI (\%) & $96.25 \pm 1.45^{\mathrm{a}}$ & $85.29 \pm 1.95^{\mathrm{b}}$ \\
FC (\%) & $82.61 \pm 1.32^{\mathrm{b}}$ & $93.13 \pm 1.12^{\mathrm{a}}$ \\
FS (\%) & $69.82 \pm 1.08^{\mathrm{b}}$ & $79.63 \pm 0.69^{\mathrm{a}}$ \\
\hline
\end{tabular}

Significant differences at $p<0.05$ in each row. WHC: Water Holding Capacity, OHC: Oil Holding Capacity, EAI: Emulsion Activity Index, ESI: Emulsion Stability Index, FC: Foaming Capacity, FS: Foaming Stability.

groups to absorb oil. In addition, the reduction of protein particle size by the ultrasonic treatment may be easier to partially dissolve in water during WHC determination, resulting in lower WHC; on the contrary, the small protein particles were more likely to bind with oil because of their larger specific surface area, leading to higher OHC. These results were similar to Fenugreek seed protein (Feyzi et al., 2015).

\subsubsection{Emulsifying properties}

Emulsification plays an important role in the manufacture of various foodstuffs. The emulsion activity index (EAI) is the measure of the amount of oil-water interfacial area stabilized by per unit weight of protein (Deng et al., 2014), and emulsion stability index (ESI) is the determination of the ability of protein to maintain emulsion stability over a certain period of time (Suresh Kumar et al., 2014). The EAI and ESI of samples calculated by Equation 4 and 5, respectively, were presented in Table 3. The ESI was recorded to be $96.25 \%$ for WSP and $85.29 \%$ for SPI, respectively. The EAI of WSP and SPI was found to be $77.57 \mathrm{~m}^{2} / \mathrm{g}$ and $56.72 \mathrm{~m}^{2} / \mathrm{g}$, respectively, which was higher than that of Torreya grandis seed protein $\left(44.57 \mathrm{~m}^{2} / \mathrm{g}\right.$ ) (Yu et al., 2017) and rice bran protein $\left(10.28 \mathrm{~m}^{2} / \mathrm{g}\right.$ ) (Phongthai et al., 2016), but lower than that of flaxseed protein $\left(87.10 \mathrm{~m}^{2} / \mathrm{g}\right)$ (Tirgar et al., 2017) and Kiwi fruit seed protein $\left(92.38 .10 \mathrm{~m}^{2} / \mathrm{g}\right.$ ) (Deng et al., 2014). The reasons for the higher EAI and ESI in WSP compared to SPI were that the relatively more hydrophobic groups on WSP molecules improved the hydrophilic-lipophilic balance and formed the stable interfacial layer for better emulsification activity (Jain \& Anal, 2016; Phongthai et al., 2016), which was confirmed by the higher OHC of WSP. Moreover, the particle size of WSP treated by ultrasonic was relatively smaller, which made the protein bind quickly at the oil-water interface, resulting in better emulsification activity.

\subsubsection{Foaming properties}

The foaming capacity (FC) is regarded as the protein flexibility and adsorption ratio at the air-water interface, while foaming stability (FS) is influenced by protein molecular rigidity (Tabtabaei et al., 2017). The FC and FS of samples obtained by Equation 6 and 7, respectively, were presented in Table 3 . As observed in Table 3, both FC and FS of WSP were significantly lower than those of SPI for $p<0.05$ but higher than that of mung bean protein (Du et al., 2018). Compared with SPI, the lower FC value for WSP can be explained by its high content of hydrophobic groups that prevented the formation of foaming
(Tabtabaei et al., 2017); while the lower FS value for WSP can be due to de-foaming effects of hydrophobic groups, and the strength of protein film and its permeability for air (Moreno et al., 2011; Tabtabaei et al., 2017).

\section{Conclusions}

This work investigated the ultrasonic-assisted extraction of a new protein from wampee seed protein. The optimal extraction parameters optimized by response surface methodology were solid-solvent ratio of 1:29 $\mathrm{g} / \mathrm{mL}$, ultrasonic time of $64 \mathrm{~min}$ and $\mathrm{pH}$ of 12 , under which the yield was $15.06 \%$. Ultrasonic time and $\mathrm{pH}$ had a significant effect on the yield, and the interactions between the three parameters also significantly affected the yield. Compared with soy protein isolate, the wampee seed protein's solubility, oil holding capacity, emulsion activity index and emulsion stability index were higher, but its water holding capacity, foaming capacity and foaming stability were lower. The wampee seed protein can be used as a promising nutraceutical and food ingredient.

\section{Acknowledgements}

This work was financially supported by Science and Technology Project of Guangdong Province (No. 2016A010105023).

\section{References}

Bradford, M. M. (1976). A rapid and sensitive method for the quantitation of microgram quantities of protein utilizing the principle of proteindye binding. Analytical Biochemistry, 72(1-2), 248-254. http://dx.doi. org/10.1016/0003-2697(76)90527-3. PMid:942051.

Carrera, C., Ruiz-Rodríguez, A., Palma, M., \& Barroso, C. G. (2012). Ultrasound assisted extraction of phenolic compounds from grapes. Analytica Chimica Acta, 732, 100-104. http://dx.doi.org/10.1016/j. aca.2011.11.032. PMid:22688040.

Castro-Muñoz, R., Yáñez-Fernández, J., \& Fíla, V. (2016). Phenolic compounds recovered from agro-food by-products using membrane technologies: an overview. Food Chemistry, 213, 753-762. http:// dx.doi.org/10.1016/j.foodchem.2016.07.030. PMid:27451244.

Chirinos, R., Aquino, M., Pedreschi, R., \& Campos, D. (2017). Optimized methodology for alkaline and enzymeassisted extraction of protein from sacha inchi (Plukenetia volubilis) kernel cake. Journal of Food Process Engineering, 40(2), 1-8. http://dx.doi.org/10.1111/jfpe.12412.

Deng, J., Liu, Q., Zhang, C., Cao, W., Fan, D., \& Yang, H. (2016). Extraction optimization of polyphenols from waste kiwi fruit seeds (Actinidia chinensis Planch.) and evaluation of its antioxidant and 
anti-inflammatory properties. Molecules (Basel, Switzerland), 21(7), 1-13. http://dx.doi.org/10.3390/molecules21070832. PMid:27347920.

Deng, J., Sun, T., Cao, W., Fan, D., Cheng, N., Wang, B., Gao, H., \& Yang, H. (2014). Extraction optimization and functional properties of proteins from Kiwi fruit (Actinidia chinensis Planch.) seeds. International Journal of Food Properties, 17(7), 1612-1625. http:// dx.doi.org/10.1080/10942912.2013.772197.

Du, M., Xie, J., Gong, B., Xu, X., Tang, W., Li, X., Li, C., \& Xie, M. (2018). Extraction, physicochemical characteristics and functional properties of Mung bean protein. Food Hydrocolloids, 76, 131-140. http://dx.doi.org/10.1016/j.foodhyd.2017.01.003.

Du, Y. Q., Liu, H., Li, C. J., Ma, J., Zhang, D., Li, L., Sun, H., Bao, X. Q., \& Zhang, D. M. (2015). Bioactive carbazole alkaloids from the stems of Clausena lansium. Fitoterapia, 103, 122-128. http://dx.doi. org/10.1016/j.fitote.2015.03.018. PMid:25804252.

Feyzi, S., Varidi, M., Zare, F., \& Varidi, M. J. (2015). Fenugreek (Trigonella foenum graecum) seed protein isolate: extraction optimization, amino acid composition, thermo and functional properties. Journal of the Science of Food and Agriculture, 95(15), 3165-3176. http://dx.doi. org/10.1002/jsfa.7056. PMid:25523830.

Ge, X. L., Shi, T., Wang, H., Zhang, J., \& Zhang, Z. Q. (2016). Development of an aqueous polyethylene glycol-based extraction and recovery method for almond (Prunus armeniaca L.) protein. Food Analytical Methods, 9(12), 3319-3326. http://dx.doi.org/10.1007/s12161-0160525-3.

He, B., Zhang, L. L., Yue, X. Y., Liang, J., Jiang, J., Gao, X. L., \& Yue, P. X. (2016). Optimization of ultrasound-assisted extraction of phenolic compounds and anthocyanins from blueberry (Vaccinium ashei) wine pomace. Food Chemistry, 204, 70-76. http://dx.doi.org/10.1016/j. foodchem.2016.02.094. PMid:26988477.

Horax, R., Hettiarachchy, N., Kannan, A., \& Chen, P. (2011). Protein extraction optimization, characterization, and functionalities of protein isolate from bitter melon (Momordica charantia) seed. Food Chemistry, 124(2), 545-550. http://dx.doi.org/10.1016/j. foodchem.2010.06.068.

Jain, S., \& Anal, A. K. (2016). Optimization of extraction of functional protein hydrolysates from chicken egg shell membrane (ESM) by ultrasonic assisted extraction (UAE) and enzymatic hydrolysis. Lebensmittel-Wissenschaft + Technologie, 69, 295-302. http://dx.doi. org/10.1016/j.lwt.2016.01.057.

Jiang, J., Chen, J., \& Xiong, Y. L. (2009). Structural and emulsifying properties of soy protein isolate subjected to acid and alkaline $\mathrm{pH}$ shifting processes. Journal of Agricultural and Food Chemistry, 57(16), 7576-7583. http://dx.doi.org/10.1021/jf901585n. PMid:19601630.

Kaur, M., \& Singh, N. (2007). Characterization of protein isolates from different Indian chickpea (Cicer arietinum L.) cultivars. Food Chemistry, 102(1), 366-374. http://dx.doi.org/10.1016/j.foodchem.2006.05.029.

Kudre, T. G., Benjakul, S., \& Kishimura, H. (2013). Comparative study on chemical compositions and properties of protein isolates from mung bean, black bean and bambara groundnut. Journal of the Science of Food and Agriculture, 93(10), 2429-2436. http://dx.doi. org/10.1002/jsfa.6052. PMid:23400865.

Suresh Kumar, K., Ganesan, K., Selvaraj, K., \& Subba Rao, P. V. (2014). Studies on the functional properties of protein concentrate of Kappaphycus alvarezii (Doty) Doty-An edible seaweed. Food Chemistry, 153, 353-360. http://dx.doi.org/10.1016/j.foodchem.2013.12.058. PMid:24491740.

Li, K., Ma, H., Li, S., Zhang, C., \& Dai, C. (2016). Effect of ultrasound on alkali extraction protein from rice dreg flour. Journal of Food Process Engineering, 40, 1-9. http://dx.doi.org/10.1111/jfpe.12377.
Moreno, S., Bialystok, E., Barac, R., Schellenberg, E. G., Cepeda, N. J., \& Chau, T. (2011). Short-term music training enhances verbal intelligence and executive function. Psychological Science in the Public Interest, 22(11), 1425-1433. http://dx.doi.org/10.1177/0956797611416999. PMid:21969312.

Odabas, H. I., \& Koca, I. (2016). Application of response surface methodology for optimizing the recovery of phenolic compounds from hazelnut skin using different extraction methods. Industrial Crops and Products, 91, 114-124. http://dx.doi.org/10.1016/j. indcrop.2016.05.033.

Phongthai, S., Lim, S. T., \& Rawdkuen, S. (2016). Optimization of microwave-assisted extraction of rice bran protein and its hydrolysates properties. Journal of Cereal Science, 70, 146-154. http://dx.doi. org/10.1016/j.jcs.2016.06.001.

Piotrowicz, I. B. B., \& Salas-Mellado, M. M. (2017). Protein concentrates from defatted rice bran: preparation and characterization. Food Science and Technology (Campinas), 37(Suppl 1), 165-172. http:// dx.doi.org/10.1590/1678-457x.34816.

Prasad, K. N., Kong, K. W., Ramanan, R. N., Azlan, A., \& Ismail, A. (2012). Selection of experimental domain using two-level factorial design to determine extract yield, antioxidant capacity, phenolics, and flavonoids from Mangifera pajang Kosterm. Separation Science and Technology, 47, 2417-2423. http://dx.doi.org/10.1080/014963 95.2012.672511.

Prasad, K. N., Xie, H., Hao, J., Yang, B., Qiu, S., Wei, X., Chen, F., \& Jiang, Y. (2010). Antioxidant and anticancer activities of 8-hydroxypsoralen isolated from wampee [Clausena lansium (Lour.) Skeels] peel. Food Chemistry, 118(1), 62-66. http://dx.doi. org/10.1016/j.foodchem.2009.04.073.

Preece, K. E., Hooshyar, N., Krijgsman, A., Fryer, P. J., \& Zuidam, N. J. (2017). Intensified soy protein extraction by ultrasound. Chemical Engineering and Processing, 113, 94-101. http://dx.doi.org/10.1016/j. cep.2016.09.003.

Roselló-Soto, E., Galanakis, C. M., Brnčić, M., Orlien, V., Trujillo, F. J., Mawson, R., Knoerzer, K., Tiwari, B. K., \& Barba, F. J. (2015). Clean recovery of antioxidant compounds from plant foods, by-products and algae assisted by ultrasounds processing. Modeling approaches to optimize processing conditions. Trends in Food Science \& Technology, 42(2), 134-149. http://dx.doi.org/10.1016/j.tifs.2015.01.002.

Saha, J., \& Deka, S. C. (2017). Functional properties of sonicated and non-sonicated extracted leaf protein concentrate from Diplazium esculentum. International Journal of Food Properties, 20(5), 10511061. http://dx.doi.org/10.1080/10942912.2016.1199034.

Şahin, S., \& Şamlı, R. (2013). Optimization of olive leaf extract obtained by ultrasound-assisted extraction with response surface methodology. Ultrasonics Sonochemistry, 20(1), 595-602. http://dx.doi.org/10.1016/j. ultsonch.2012.07.029. PMid:22964032.

Shen, D. Y., Chao, C. H., Chan, H. H., Huang, G. J., Hwang, T. L., Lai, C. Y., Lee, K. H., Thang, T. D., \& Wu, T. S. (2012). Bioactive constituents of Clausena lansium and a method for discrimination of aldose enantiomers. Phytochemistry, 82, 110-117. http://dx.doi. org/10.1016/j.phytochem.2012.06.019. PMid:22818357.

Tabtabaei, S., Hijar, B., Chen, B. K., \& Diosady, L. L. (2017). Functional properties of protein isolates produced by aqueous extraction of de-hulled yellow mustard. Journal of the American Oil Chemists Society, 94(1), 149-160. http://dx.doi.org/10.1007/s11746-016-2922-6.

Tirgar, M., Silcock, P., Carne, A., \& Birch, E. J. (2017). Effect of extraction method on functional properties of flaxseed protein concentrates. Food Chemistry, 215, 417-424. http://dx.doi.org/10.1016/j. foodchem.2016.08.002. PMid:27542494. 
Tomšik, A., Pavlić, B., Vladić, J., Ramić, M., Brindza, J., \& Vidović, S. (2016). Optimization of ultrasound-assisted extraction of bioactive compounds from wild garlic (Allium ursinum L.). Ultrasonics Sonochemistry, 29, 502-511. http://dx.doi.org/10.1016/j. ultsonch.2015.11.005. PMid:26563916.

Wu, H., Wang, Q., Ma, T., \& Ren, J. (2009). Comparative studies on the functional properties of various proteins concentrate preparations of peanut protein. Food Research International, 42(3), 343-348. http:// dx.doi.org/10.1016/j.foodres.2008.12.006.

Xia, N., Wang, J. M., Gong, Q., Yang, X. Q., Yin, S. W., \& Qi, J. R. (2012). Characterization and In Vitro digestibility of rice protein prepared by enzyme-assisted microfluidization: Comparison to alkaline extraction. Journal of Cereal Science, 56(2), 482-489. http://dx.doi. org/10.1016/j.jcs.2012.06.008.

Xie, J. H., Dong, C. J., Nie, S. P., Li, F., Wang, Z. J., Shen, M. Y., \& Xie, M. Y. (2015). Extraction, chemical composition and antioxidant activity of flavonoids from Cyclocarya paliurus (Batal.) Iljinskaja leaves. Food Chemistry, 186, 97-105. http://dx.doi.org/10.1016/j. foodchem.2014.06.106. PMid:25976797.

Xu, X., Xie, H., \& Wei, X. (2014). Jasmonoid glucosides, sesquiterpenes and coumarins from the fruit of Clausena lansium. LebensmittelWissenschaft + Technologie, 59(1), 65-69. http://dx.doi.org/10.1016/j. lwt.2014.04.033.
Xu, Y., Cai, F., Yu, Z., Zhang, L., Li, X., Yang, Y., \& Liu, G. (2016). Optimisation of pressurised water extraction of polysaccharides from blackcurrant and its antioxidant activity. Food Chemistry, 194, 650-658. http://dx.doi.org/10.1016/j.foodchem.2015.08.061. PMid:26471604.

Yan, F., Fan, K., He, J., \& Gao, M. (2016). Ultrasonic-assisted solvent extraction of carotenoids from rapeseed meal: Optimization using response surface methodology. Journal of Food Quality, 38(6), 377386. http://dx.doi.org/10.1111/jfq.12154.

Yllmaz, E., \& Hüriyet, Z. (2017). Physico-chemical and functional properties of extracted capia pepperseed (Capsicum annuum L.) proteins. Waste and Biomass Valorization, 8(3), 871-881. http:// dx.doi.org/10.1007/s12649-016-9633-y.

Yu, M., Zeng, M., Qin, F., He, Z., \& Chen, J. (2017). Physicochemical and functional properties of protein extracts from Torreya grandis seeds. Food Chemistry, 227, 453-460. http://dx.doi.org/10.1016/j. foodchem.2017.01.114. PMid:28274456.

Zou, Y., Wang, L., Li, P., Cai, P., Zhang, M., Sun, Z., Sun, C., Geng, Z., Xu, W., Xu, X., \& Wang, D. (2017). Effects of ultrasound assisted extraction on the physiochemical, structural and functional characteristics of duck liver protein isolate. Process Biochemistry, 52, 174-182. http:// dx.doi.org/10.1016/j.procbio.2016.09.027. 